\title{
Probiotic Crescenza Cheese Containing Lactobacillus casei and Lactobacillus acidophilus Manufactured with High-Pressure Homogenized Milk
}

\author{
P. Burns, ${ }^{*}$ F. Patrignani, $\dagger^{1}$ D. Serrazanetti, $† \ddagger$ G. C. Vinderola, ${ }^{\star}$ J. A. Reinheimer, ${ }^{\star}$ R. Lanciotti, $\dagger$ \\ and M. E. Guerzoni† \\ *Instituto de Lactología Industrial (INLAIN), Facultad de Ingeniería Química, Universidad Nacional del Litoral, \\ Santiago del Estero 2829, 3000, Santa Fe, Argentina \\ †Dipartimento di Scienze degli Alimenti, University of Bologna, p.zza Goidanich 60, 47023, Cesena, Italy \\ fDipartimento di Scienze degli Alimenti, University of Teramo, via C. Lerici 1, 64023, Mosciano Sant' Angelo-Teramo, Italy
}

\begin{abstract}
High-pressure homogenization (HPH) is one of the most promising alternatives to traditional thermal treatment of food preservation and diversification. Its effectiveness on the deactivation of pathogenic and spoilage microorganisms in model systems and real food is well documented. To evaluate the potential of milk treated by HPH for the production of Crescenza cheese with commercial probiotic lactobacilli added, 4 types of cheeses were made: $\mathrm{HPH}$ (from HPH-treated milk), P (from pasteurized milk), HPH-P (HPH-treated milk plus probiotics), and P-P (pasteurized milk plus probiotics) cheeses. A strain of Streptococcus thermophilus was used as starter culture for cheese production. Compositional, microbiological, physicochemical, and organoleptic analyses were carried out at 1, 5, 8, and $12 \mathrm{~d}$ of refrigerated storage $\left(4^{\circ} \mathrm{C}\right)$. According to results obtained, no significant differences among the 4 cheese types were observed for gross composition (protein, fat, moisture) and $\mathrm{pH}$. Differently, the HPH treatment of milk increased the cheese yield about $1 \%$ and positively affected the viability during the refrigerated storage of the probiotic bacteria. In fact, after $12 \mathrm{~d}$ of storage, the Lactobacillus paracasei A13 cell loads were 8 log cfu/ $\mathrm{g}$, whereas Lactobacillus acidophilus H5 exhibited, in P-P cheese, a cell load decrease of about $1 \mathrm{log} \mathrm{cfu} / \mathrm{g}$ with respect to the HPH-P cheese. The hyperbaric treatment had a significant positive effect on free fatty acids release and cheese proteolysis. Also, probiotic cultures affected proteolytic and lipolytic cheese patterns. No significant differences were found for the sensory descriptors salty and creamy among HPH and P cheeses as well as for acid, piquant, sweet, milky, salty, creamy,
\end{abstract}

Received July 11, 2007.

Accepted October 19, 2007.

${ }^{1}$ Corresponding author: francesca.patrignani@unibo.it and overall acceptance among HPH, HPH-P, and P-P Crescenza cheeses.

Key words: high-pressure homogenization, Crescenza, probiotic cheese

\section{INTRODUCTION}

The recognition of dairy products with probiotic bacteria as functional foods that provide health benefits beyond basic nutrition and the emerging clinical evidence to their potential in preventing some diseases have notably enlarged their consumption and stimulated innovation and new product development (Boylston et al., 2004; Ong et al., 2007). Although yogurt and fermented milks have received the most attention as carriers of probiotic bacteria, some cheese varieties such as Gouda (Gomes et al., 1995), Argentinean Fresco cheese (Vinderola et al., 2000), white cheese (Kasımoglu et al., 2004), Arzua-Ulloa (Menéndez et al., 2000), Minas fresh cheese (Buriti et al., 2005), Cheddar (Ong et al., 2007), cottage cheese (Blanchette et al., 1996), Crescenza (Gobbetti et al., 1998), caprine (Kalavrouzioti et al., 2005), Estonian Pikantne cheese (Songisepp et al., 2004), and Canestrato Pugliese (Corbo et al., 2001) have also been studied as vehicles of probiotic microorganisms.

Cheeses have a number of advantages over yogurt and fermented milks as a delivery system for viable probiotic microorganisms, because they generally have higher $\mathrm{pH}$ and buffering capacity, more solid consistency, and relatively higher fat content (Boylston et al., 2004; Ong et al., 2007). These features give protection to probiotic bacteria during storage and passage through the gastrointestinal tract. To exert positive health effects, the microorganisms need to be viable, active, and sufficiently abundant, in concentrations of at least $10^{6} \mathrm{cfu} / \mathrm{g}$ throughout the shelf life (Vinderola et al., 2000). Most publications concerning incorporation of probiotic bacteria into cheeses have focused on 
their survival during manufacture and storage, but few studies have considered also the effect of this incorporation on cheese organoleptic properties (Gobbetti et al., 1998; Buriti et al., 2005). Moreover, most research has been centered on probiotic strains of bifidobacteria (alone or mixed with lactobacilli strains) in cheeses manufactured with mesophilic starters (Ross et al., 2002). On the contrary, there are few studies on cheeses produced with thermophilic starter cultures carrying probiotic lactobacilli instead (Gobbetti et al., 1998; Bergamini et al., 2006).

High-pressure homogenization (HPH) is one of the most promising alternatives to traditional thermal treatment of food preservation and diversification. Its effectiveness on the deactivation of pathogenic and spoilage microorganisms in model systems and real food is well documented (Guerzoni et al., 2002; Brinpez et al., 2006), stimulating research on the application of HPH for food safety and shelf life improvement. However, its effectiveness in the reduction of cell load depends on several factors such as the severity of treatment, the inlet temperature of the sample, the medium composition, as well as the strain and species sensitivities (Diels and Michiels, 2006). In addition to the modifications of the microbiota of the raw material, the HPH treatment of milk is reported to induce significant changes of the microbial populations able to grow in the product during ripening or storage (Lanciotti et al., 2004a,b, 2006, 2007a). The HPH treatment acts also on food constituents, especially proteins, fat, and polysaccharides, with consequent modification of their functional properties and susceptibility to enzymatic attack as well as of food microstructure (Sandra and Dalgleish, 2005).

Crescenza is a soft, rindless, very popular Italian cheese with a short ripening time and is produced with thermophilic acidifying starters. Technology and starter selection of Crescenza cheese have been standardized and reviewed in depth (Neviani and Giraffa, 1993). Its characteristics and high content of viable lactic acid bacteria fit well with the concept of probiotic dairy products (Gobbetti et al., 1998). In fact, analogously to other fresh cheeses, it appears to be suitable to serve as a carrier for probiotic bacteria, because no prolonged periods of ripening are necessary, and storage occurs at refrigeration temperatures (Heller et al., 2003). However, long-term ripened cheeses have also been reported as suitable carriers for probiotic bacteria (Phillips et al., 2006).

The overall aim of the present study was to evaluate the potential of milk HPH treatment of the production of Crescenza cheese carrying probiotic bacteria. More specifically, the purpose was to examine the viability of commercial probiotic cultures of Lactobacillus acido- philus and Lactobacillus paracasei, added as adjunct cultures during production, and the implications of their addition in the physicochemical and sensory characteristics of the product obtained.

\section{MATERIALS AND METHODS}

\section{Probiotic Bacteria and Starter Culture Conditions}

Two commercially available probiotic strains ( $L$. paracasei A13 and L. acidophilus H5) were used in this study. They were those used for design of the probiotic Fresco cheese (Vinderola et al., 2000), whose immunomodulating effects in the gut were demonstrated (Medici et al., 2004). Overnight cultures $\left(37^{\circ} \mathrm{C}\right.$ for $\left.16 \mathrm{~h}\right)$ of the probiotic bacteria were obtained in de Man-RogosaSharpe (MRS) broth (Biokar, Beauvais, France). Cells were harvested by centrifugation at $8,000 \times g$ for 20 $\min$ at $4^{\circ} \mathrm{C}$. The resultant pellet was washed twice with saline solution $(0.9 \% \mathrm{NaCl}$ in distilled water $)$ and resuspended in $10 \%$ sterile skim milk (Oxoid, Basingstoke, UK). A commercial freeze-dried culture (Streptococcus thermophilus St 0.20, Sacco S.R.L., Como, Italy) was used as an acidifying starter for cheese production. The culture was reactivated in $500 \mathrm{~mL}$ of sterile milk at $42^{\circ} \mathrm{C}$, according to the instructions of the manufacturer, to have an inoculum level of $6 \log \mathrm{cfu} / \mathrm{mL}$.

\section{Milk Treatments}

For each cheesemaking, $20 \mathrm{~L}$ of raw milk was homogenized at $100 \mathrm{MPa}$ using a 1-stage continual high-pressure homogenizer PANDA (Niro Soavi, Parma, Italy) equipped with a valve with a flow rate of $10 \mathrm{~L} / \mathrm{h}$. The milk inlet temperature was approximately $5^{\circ} \mathrm{C}$; the temperature increase during homogenizing treatment was monitored at the outlet product point. The milk outlet temperature did not exceed $30 \pm 2^{\circ} \mathrm{C}$, and milk was then collected in receiving containers and immediately refrigerated at $4^{\circ} \mathrm{C}$ for $12 \mathrm{~h}$. The industrial pasteurization treatment was performed on $20 \mathrm{~L}$ of milk at $72.5^{\circ} \mathrm{C}$ for $15 \mathrm{~s}$ according to the procedures adopted by the dairy farm, and the pasteurized milk was immediately cooled to $40^{\circ} \mathrm{C}$.

\section{Cheesemaking, Yield, and Compositional Analyses}

Four different Crescenza-type cheeses were manufactured: HPH cheese (cheese from high-pressure homogenized milk), $\mathrm{P}$ cheese (cheese from pasteurized milk), HPH P-cheese (cheese from high-pressure homogenized milk plus probiotic cultures), and P-P cheese (cheese from pasteurized milk plus probiotic bacteria). For each cheese type, $10 \mathrm{~L}$ of treated milk was used. Four grams per liter of acidulant (Lacmon S, Sacco S.R.L.) was 
added to aliquots of milk kept at $40^{\circ} \mathrm{C}$. After 5 min, 500 $\mathrm{mL}$ of the starter culture (S. thermophilus St 0.20 ) was added to attain in milk an initial inoculum of $6 \log \mathrm{cfu} /$ $\mathrm{mL}$. Fresh cultures of $L$. paracasei and $L$. acidophilus obtained in MRS broth were washed twice with saline solution, resuspended in milk, and added to the batches for the production of HPH-P or P-P cheeses to attain an initial count in cheese of ca. $7.5 \mathrm{log} \mathrm{cfu} / \mathrm{g}$. When the $\mathrm{pH}$ of the inoculated milks reached a value of 6.35 , seven grams per liter of salt ( $\mathrm{NaCl}$, Carlo Erba, Milan, Italy) was added. Additionally, $3 \mathrm{~mL}$ of commercial rennet (12,500 U, 20\% pepsin, $80 \%$ chymosin, Concorde, Novara, Italy) was added to the batches. Coagulation occurred during the following $15 \mathrm{~min}$. After curd cutting and resting (45 min), curds were separated from whey and placed into perforated hoops (plastic cheese molds) until they reached a $\mathrm{pH}$ value of 5.15 according to the industrial procedures normally adopted and to suggestions proposed by Neviani and Giraffa (1993) and Gobbetti et al. (1998). Finally, the cheeses were stored at $4^{\circ} \mathrm{C}$.

The cheese-making procedures were repeated in the same cheese dairy plant on 3 consecutive days with milk from the same farm. The raw milk from cows used in this study had the following mean composition: protein $3.59 \%$, fat $4.20 \%$, and $\mathrm{pH}$ 6.76. Cheesemaking was performed at a local dairy farm (Mambelli, Bertinoro, Italy). The microbiological and chemicophysical analyses were performed in duplicate on 3 samples (produced on 3 different days) of each cheese type and, consequently, the data are means of 3 repetitions and 2 replicates.

The cheese yields were calculated as the percentage ratio between the weights of the milk used and the cheeses obtained. Gross composition of the cheese milk and cheeses at the end of the ripening was assessed according to IDF standards. Milk protein and fat content were determined by the IDF procedures (1993 and 1986, respectively), whereas cheese fat matter, moisture, and protein content were quantified by IDF method, respectively (1986, 1970, 1964).

Compositional, microbiological, and physicochemical analysis were carried out after $1,5,8$, and $12 \mathrm{~d}$ of refrigerated storage.

\section{Microbiological Analysis and pH Measurement}

For the enumeration of the different microbial groups in milk, $10 \mathrm{~mL}$ of sample was diluted in $90 \mathrm{~mL}$ of $2 \%$ (wt/vol) sodium citrate sterile solution, whereas $20 \mathrm{~g}$ of cheese representative of the whole cheese was placed in $180 \mathrm{~mL}$ of $2 \%$ (wt/vol) sodium citrate sterile solution and homogenized in a stomacher (Lab-Blender 80, Pbi International, Milan, Italy) for $3 \mathrm{~min}$. Decimal dilutions of the homogenates were made in $0.1 \%$ (wt/vol) peptone solution, and $0.1 \mathrm{~mL}$ of appropriate dilutions was spread onto the surface of agar media. Streptococcus thermophilus was enumerated on M17 (Biokar; $37^{\circ} \mathrm{C}$, 48 h). Lactobacillus paracasei and L. acidophilus were enumerated $\left(37^{\circ} \mathrm{C}, 48 \mathrm{~h}\right)$ on MRS-lithium propionate agar (Vinderola and Reinheimer, 1999) and MRS-bile agar (IDF, 1995), respectively. The total lactic microflora was determined in plate count agar (Oxoid) added to $10 \%$ skim milk powder (Oxoid) at $37^{\circ} \mathrm{C}$ for 48 h. Sabouraud dextrose agar (Oxoid) was used for yeast count $\left(30^{\circ} \mathrm{C}, 48 \mathrm{~h}\right)$. Microstaphylococci and enterococci were counted by surface-plating on Baird-Parker (with added egg yolk tellurite emulsion) and Slanetz and Bartley media (Oxoid), respectively $\left(37^{\circ} \mathrm{C}, 48 \mathrm{~h}\right)$. Enterobacteriaceae were determined on violet red bile glucose agar (Oxoid; $37^{\circ} \mathrm{C}, 24 \mathrm{~h}$ ). Lactic acid bacteria were enumerated on MRS (bacilli) and M17 (cocci) agar, respectively (Biokar), incubating the plates at $37^{\circ} \mathrm{C}$ for 48 h. For the detection of the natural occurring Listeria monocytogenes, the method suggested by McClain and Lee (1988) was followed, whereas the occurrence of Salmonella spp. was investigated according to the method proposed by Andrews and Hammack (1998). Escherichia coli was investigated on violet red bile agar (Oxoid) added to 4-methylumbelliferyl- $\beta$-D-glucuronide (Oxoid), incubating the plates at $37^{\circ} \mathrm{C}$ for $24 \mathrm{~h}$. Staphylococcus aureus was enumerated on Baird-Parker media (Oxoid) with added egg yolk tellurite emulsion (Oxoid) after $24 \mathrm{~h}$ at $37^{\circ} \mathrm{C}$.

The milk and cheese $\mathrm{pH}$ were measured by using a pH meter, Hanna Instruments 8519 (Incofar, Modena, Italy), on $10 \mathrm{~mL}$ of milk and $10 \mathrm{~g}$ of sample diluted in $10 \mathrm{~mL}$ of distilled water, respectively.

\section{Proteolysis, Lipolysis, and AA Assessment}

The evolution of proteolysis of different cheeses was monitored by SDS-PAGE electrophoresis. The SDSPAGE was performed in a vertical gel lab system, Hoefer SE 600 Series (Amersham Pharmacia Biotech, Bucks, UK), according to the method of Laemmli (1970).

Sample loading volume and concentrations of separating and stacking gels were $20 \mu \mathrm{L}, 15 \%$, and 5\% acrylamide-bisacrylamide, respectively. Protein and peptide extracts were prepared, according to the method of Kuchroo and Fox (1982), as follows: $5 \mathrm{~g}$ of cheese was homogenized with $20 \mathrm{~mL}$ water, using a stomacher, for $3 \mathrm{~min}$ at $20^{\circ} \mathrm{C}$ and incubated for $1 \mathrm{~h}$ at $40^{\circ} \mathrm{C}$ at $\mathrm{pH} 4.6$ (adjusted with $0.1 \mathrm{~N} \mathrm{HCl).} \mathrm{The} \mathrm{sample} \mathrm{was} \mathrm{centrifuged}$ at $3,000 \times g$ for $20 \mathrm{~min}$ at $5^{\circ} \mathrm{C}$, and the pellet was suspended in $5 \mathrm{~mL}$ of $7 M$ urea and stored in a freezer at $-20^{\circ} \mathrm{C}$ until SDS-PAGE analysis. Before analysis, $150 \mathrm{mg}$ of the suspension was mixed with $2.5 \mathrm{~mL}$ of 
$0.166 M$ Tris- $1 \mathrm{~m} M$ EDTA, $\mathrm{pH} 8$, and $2.5 \mathrm{~mL}$ of $7 \%$ SDS and centrifuged at $5,000 \times g$ for $20 \mathrm{~min}$ at $4^{\circ} \mathrm{C}$. Protein and large peptide solutions were prepared by heating 1-mL supernatants for $5 \mathrm{~min}$ at $95^{\circ} \mathrm{C}$ and adding 0.2 $\mathrm{mL}$ of $\beta$-mercaptoethanol. Glycerol $(0.2 \mathrm{~mL})$ and $0.2 \mathrm{~mL}$ of bromophenol $(0.02 \%)$ were added to the sample before loading on the gel. The SDS-PAGE Molecular Weight Standard Broad Range (BioRad Laboratories, München, Germany) was used as a molecular mass marker. After running, the gel was stained in a solution composed of $0.3 \mathrm{mM}$ Coomassie Blue, $40 \%$ methanol. and $7 \%$ glacial acetic acid. After that, the gel was discolored in a 5\% methanol and 7\% glacial acetic acid solution for $15 \mathrm{~h}$.

The presence of FFA in the 4 cheese types was assessed immediately after 1 and $12 \mathrm{~d}$ of refrigerated storage. Cheese lipid extraction was performed as described by de Jong and Badings (1990). The pooled diethyl ether-heptane extract was applied to a Bond Elut aminopropyl column ( $3 \mathrm{~mL}$, containing $500 \mathrm{mg}$ of silica modified with aminopropyl groups, IST, Mid Glamorgan, UK) that was conditioned with $10 \mathrm{~mL}$ of heptane. The FFA were eluted with $10 \mathrm{~mL}$ of diethyl ether containing 2\% (vol/vol) formic acid. For GC analyses, an Agilent Hewlett-Packard 6890GC gas chromatograph (Agilent Technologies, Milano, Italy) equipped with an MS detector, Hewlett-Packard 5970 MSD (HewlettPackard, Geneva, Switzerland), and a $30 \mathrm{~m} \times 0.32$ i.d. fused silica capillary column coated with a $0.2-\mu \mathrm{m}$ film of Carbowax (Supelco, Sigma-Aldrich, Steinheim, Germany), as a stationary phase, was used. The conditions were as follows: injection temperature, $250^{\circ} \mathrm{C}$; detector temperature, $250^{\circ} \mathrm{C}$; carrier gas $(\mathrm{He})$ flow rate, $1.5 \mathrm{~mL} /$ $\mathrm{min}$; and splitting ratio, 1:50 (vol/vol). The oven temperature was held at $50^{\circ} \mathrm{C}$ for $2 \mathrm{~min}$, then the temperature increased to $220^{\circ} \mathrm{C}$ at $4^{\circ} \mathrm{C} / \mathrm{min}$, and the oven was held at the final temperature for $8 \mathrm{~min}$. The identification of the individual FFA of cheese samples was based on comparison of the retention times of the unknown FFA with those obtained from the known FFA standards (Sigma-Aldrich). Moreover, the identification of FFA was carried out by computer matching of their mass spectral data with those of the compounds contained in the Agilent Hewlett-Packard NIST 98 and Wiley vers. 6 mass spectral database. The quantification of FFA level of cheese samples was performed using C13:0 as an internal standard at a concentration of $2 \mathrm{mg} / \mathrm{mL}$.

The reverse-phase HPLC analysis of the free AA (FAA) was performed according to the method used previously by Izco et al. (2000) at the cheese expire date. The HPLC equipment (Waters Corporation, Milford, MA) consisted of 2 M510 pumps connected to an ULTRA WISP 715 injector. The Waters Pico-Tag C18 reversed-phase column (Waters, Milano, Italy) was heated in a temperature-control module at $46^{\circ} \mathrm{C}$, and the resolved peaks were detected using an M966 photodiode array detector set at $254 \mathrm{~nm}$ and an NEC PowerMate 486/33i computer, employing Millennium 2010 software for quantification. For identification and quantification of FAA, a master solution of AA (Sigma-Aldrich) was used, to which methionine sulfone (SigmaAldrich) was added as an internal standard. A gradient with 2 solvents was used to run the samples: solution A comprised $70 \mathrm{~m} M$ sodium acetate adjusted to $\mathrm{pH} 6.55$ with acetic acid and treated with $2.5 \%$ acetonitrile, and solution B was $45 \%$ acetonitrile, $40 \%$ water, and $15 \%$ methanol. Before each injection, the column was equilibrated with solvent A for $20 \mathrm{~min}$.

\section{Volatile Profile Assessment}

Volatile compounds were monitored after 1 and $12 \mathrm{~d}$ of cheese-refrigerated storage, using GC-MS coupled with a solid-phase microextraction (GC-MS-SPME) technique. For each cheese, $5 \mathrm{~g}$ of samples was placed in $10-\mathrm{mL}$ sterilized vials, and the vials were sealed by polytetrafluoroethylene/silicon septa. The samples were then equilibrated for $20 \mathrm{~min}$ at $50^{\circ} \mathrm{C}$, and volatiles were adsorbed on a fused silica fiber covered by $75 \mu \mathrm{m}$ of carboxen polydimethyl siloxane (Supelco) for $40 \mathrm{~min}$. Adsorbed molecules were desorbed in the gas chromatograph for $5 \mathrm{~min}$. For peak detection, an Agilent HewlettPackard 6890 GC gas chromatograph (Agilent Technologies) equipped with an MS detector, $5970 \mathrm{MSD}$ (Hewlett-Packard), and a $50 \mathrm{~m} \times 0.32$ i.d. fused silica capillary column coated with a $1.2-\mu \mathrm{m}$ polyethylenglycol film (Chrompack CP-Wax 52 CB, Middelburg, the Netherlands) as stationary phase were used. The conditions were as follows: injection temperature, $250^{\circ} \mathrm{C}$; detector temperature, $250^{\circ} \mathrm{C}$; carrier gas $(\mathrm{He})$ flow rate, $1 \mathrm{~mL} /$ min; splitting ratio, 1:20 ( $\mathrm{vol} / \mathrm{vol})$. The oven temperature was programmed as follows: $50^{\circ} \mathrm{C}$ for $1 \mathrm{~min}$; from $50^{\circ} \mathrm{C}$ to $65^{\circ} \mathrm{C}$, at $4.5^{\circ} \mathrm{C} / \mathrm{min}$; from $65^{\circ} \mathrm{C}$ to $230^{\circ} \mathrm{C}$, at $10^{\circ} \mathrm{C} /$ min; then holding for $25 \mathrm{~min}$. Volatile peak identification was carried out by computer matching of mass spectral data with those of the compounds contained in the Agilent Hewlett-Packard NIST 98 and Wiley version 6 mass spectral database. The GC-MS-SPME analyses were performed sampling 3 vials for each considered cheese.

\section{Organoleptic Evaluation}

To evaluate and compare the sensory attributes of the different cheeses obtained, a panel test was performed after $8 \mathrm{~d}$ of refrigerated storage. Twenty-five trained evaluators tasted $20 \mathrm{~g}$ of each sample served at $15^{\circ} \mathrm{C}$ under controlled conditions of environment and light 
according to Standard 8589 (ISO, 1988), as suggested by Gallardo-Escamilla et al. (2007). The assessors were asked to evaluate cheese color, flavor, firmness, appearance, acid, piquant, bitter, sweet, milky, salty, creamy, and overall impression attributing a score ranging from 0 (low or poor) to 10 (high or very excellent).

\section{DNA Extraction, Amplification, and Denaturing Gradient Gel Electrophoresis}

Genomic DNA from pure cultures was extracted with the Insta Gene Matrix kit (BioRad, Milano, Italy), whereas the total DNA existing in the cheese extraction was carried out with kit mo-bio (Cambrex Biosciences, Bergamo, Italy). The PCR amplification of approximately $200 \mathrm{bp}$ of the V2-V3 variable region of the $16 \mathrm{~S}$ rRNA gene was obtained using the primers HDA1-GC (5'-AC TCC TCC TAC GGG AGG CAG CAG-3'; a 40bp GC clamp was attached to the $5^{\prime}$ end of that primer) and HAD2 (5'-GTA TTA CCG CGG CTG CTG GCA-3'; Walter et al., 2000).

This PCR reaction was performed in total reaction volume of $40 \mathrm{~mL}$ containing $0.5 \mathrm{~m} M$ of each of the primers, $200 \mathrm{~m} M$ of each deoxynucleoside triphosphate (Takara, Otsu, Shiga, Japan), $2.5 \mathrm{mM} \mathrm{MgCl} 2$ (Takara), $0.5 \mathrm{U}$ of Taq DNA polymerase (Takara), $1 \times$ PCR buffer (Takara), and $10 \mu \mathrm{g} / \mathrm{mL}$ of the isolated DNA (Theunissen et al., 2005). The amplification program was as follows: $94^{\circ} \mathrm{C}$ for $4 \mathrm{~min}, 30$ cycles of $94^{\circ} \mathrm{C}$ for $30 \mathrm{~s}, 56^{\circ} \mathrm{C}$ for $30 \mathrm{~s}, 72^{\circ} \mathrm{C}$ for $60 \mathrm{~s}$, and then $72^{\circ} \mathrm{C}$ for $8 \mathrm{~min}$ (Fasoli et al., 2003). The PCR were performed in a T3000 Thermocycler (Biometra, Göttingen, Germany).

The PCR fragments were separated by denaturing gradient gel electrophoresis using the BioRad DCode Universal Mutation Detection System (BioRad Laboratories). Separation of the PCR amplicons was obtained by the direct application of the PCR products onto 8\% (wt/vol) polyacrylamide gels in $0.5 \times$ Tris-acetate EDTA buffer containing a linear denaturant gradient of 30 to $70 \%$. The $100 \%$ denaturing solution contained $40 \%$ (vol/ vol) formamide and 7.9 $\mathrm{M}$ urea. Gels were electrophoresed for $6 \mathrm{~h}$ at $60^{\circ} \mathrm{C}$ with constant voltage of $130 \mathrm{~V}$, stained with ethidium bromide, rinsed in distilled water, and photographed under UV illumination (Theunissen et al., 2005). A DNA mix, composed by mixing equal amounts of amplicons obtained from DNA of the strains studied of S. thermophilus, L. casei, and L. acidophilus, was used as a control.

\section{Statistical Analysis of Data}

The data were analyzed by 1-way ANOVA using the statistical package Statistica for Windows 6.1 (Statsoft Inc., Tulsa, OK). The ability of each descriptor to dis-
Table 1. Microbial population ( $\log \mathrm{cfu} / \mathrm{mL} \pm \mathrm{SD}$ ) of raw, high-pressure homogenized, and pasteurized milk

\begin{tabular}{lccc}
\hline & \multicolumn{3}{c}{ Treatment $^{1}$} \\
\cline { 2 - 4 } Microbial group & $\mathrm{R}$ & $\mathrm{HPH}$ & $\mathrm{P}$ \\
\hline Total microflora & $4.0 \pm 0.2^{\mathrm{a}}$ & $3.8 \pm 0.3^{\mathrm{ab}}$ & $3.2 \pm 0.2^{\mathrm{b}}$ \\
Yeasts & $3.0 \pm 0.3^{\mathrm{a}}$ & $1.6 \pm 0.3^{\mathrm{b}}$ & $2.0 \pm 0.5^{\mathrm{ab}}$ \\
Enterococci & $2.0 \pm 0.2^{\mathrm{a}}$ & $1.6 \pm 0.3^{\mathrm{ab}}$ & $1.0 \pm 0.2^{\mathrm{b}}$ \\
Microstaphylococci $^{2}$ & $3.0 \pm 0.3^{\mathrm{a}}$ & $3.2 \pm 0.3^{\mathrm{a}}$ & $2.1 \pm 0.3^{\mathrm{b}}$ \\
LAB $^{2}$ (bacilli) & $4.0 \pm 0.2^{\mathrm{a}}$ & $4.2 \pm 0.4^{\mathrm{a}}$ & $1.9 \pm 0.1^{\mathrm{b}}$ \\
LAB $^{\mathrm{a}}$ cocci) & $4.3 \pm 0.4^{\mathrm{a}}$ & $4.3 \pm 0.3^{\mathrm{a}}$ & $3.6 \pm 0.4^{\mathrm{a}}$ \\
Enterobacteriaceae & $2.0 \pm 0.2^{\mathrm{a}}$ & $0.8 \pm 0.3^{\mathrm{b}}$ & $1.2 \pm 0.2^{\mathrm{b}}$ \\
\hline
\end{tabular}

${ }^{\mathrm{a}, \mathrm{b}}$ For each line considered, values with the same superscript are not statistically different $(P>0.05)$.

${ }^{1}$ Treatments: $\mathrm{R}=$ raw milk; HPH = high-pressure-treated milk; $\mathrm{P}=$ pasteurized milk.

${ }^{2} \mathrm{LAB}=$ lactic acid bacteria.

criminate between samples was investigated according to the posthoc comparisons of the ANOVA.

\section{RESULTS}

\section{Raw Milk Composition, Crescenza Cheese Yield, and Gross Composition}

Some physicochemical parameters of the raw milk were as follows: $\mathrm{pH} 6.76 \pm 0.04$, protein $3.59 \% \pm 0.10$ (wt/wt), and fat $4.20 \% \pm 0.15$ (wt/wt). The microbiological data of raw, pasteurized, and high-pressure-treated milk are reported in Table 1 . The HPH treatment was significantly less effective $(P<0.05)$ than pasteurization in the reduction of total lactobacilli and microstaphylococci, whereas no significant differences were found between both treatments for lactococci and streptococci, yeast, Enterobacteriaceae, and enterococci, that resulted always below $2.0 \mathrm{log} \mathrm{cfu} / \mathrm{mL}$. Listeria monocytogenes and Salmonella spp. were never found, whereas $E$. coli and $S$. aureus were always under the detection limits $(1 \log \mathrm{cfu} / \mathrm{mL})$. The $\mathrm{pH}$ data, recorded immediately before the addition of probiotic and starter cultures and rennet ( $12 \mathrm{~h}$ after the $\mathrm{HPH}$ treatment), showed a decrease of 0.23 in high-pressure-treated milk with respect to pasteurized milk that had a $\mathrm{pH}$ of 6.55 \pm 0.02 . After $12 \mathrm{~d}$ of refrigerated storage, cheese gross composition was determined. No significant differences were observed in relation to the milk treatment and probiotic adjuncts. The protein, fat, and moisture mean contents (as \%) for HPH cheese (from high-pressure homogenized milk) and $\mathrm{P}$ cheese (from pasteurized milk) were $13.14 \pm 2.13,20.50 \pm 2.50$, and $63.18 \pm 3.27$ and $13.14 \pm 1.80,23.50 \pm 2.30$, and $60.00 \pm 3.40$, respectively, whereas for HPH-P cheese (from high-pressure homogenized milk plus probiotic cultures) and P-P cheese (from pasteurized milk plus probiotic bacteria), 
Table 2. Enumeration ( $\log \mathrm{cfu} / \mathrm{g} \pm \mathrm{SD}$ ) of microflora in different Crescenza cheese types over the ripening time

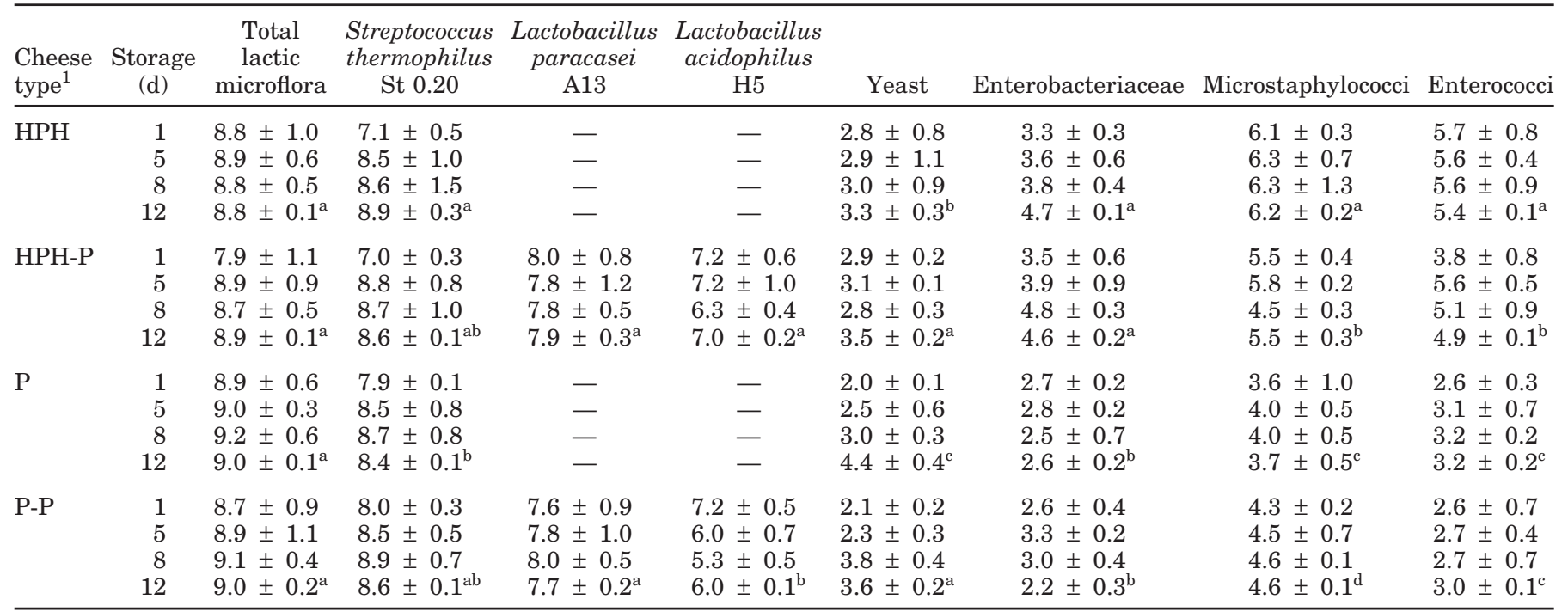

${ }^{\mathrm{a}-\mathrm{d}}$ For each column considered, values from 12-d-old samples with the same superscript are not statistically different $(P>0.05)$

${ }^{1} \mathrm{HPH}=$ Crescenza cheese from high-pressure homogenized milk; HPH-P = Crescenza cheese from high-pressure homogenized milk with added probiotic bacteria; $\mathrm{P}=$ Crescenza cheese from pasteurized milk; $\mathrm{P}-\mathrm{P}=$ Crescenza cheese from pasteurized milk with added probiotic bacteria.

the values obtained were $14.29 \pm 1.80,21.00 \pm 2.15$, and $61.83 \pm 3.10$ and $14.99 \pm 1.20,20.00 \pm 2.00$, and $62.25 \pm 3.20$, respectively. All the data were within the limits reported for the gross composition of Crescenza cheese (Bottazzi, 1993).

The HPH treatment of milk significantly increased $(P<0.05)$ the cheese yield by about $1.0 \%$. However, this parameter was not significantly modified by the addition of probiotic cultures (data not shown).

The presence of $L$. acidophilus and $L$. paracasei resulted in a significant $(P<0.05)$ decrease of the cheese $\mathrm{pH}$ during the storage independently from the milk treatment ( $\mathrm{HPH}$ or pasteurization). In fact, $\mathrm{pH}$ values lower than 5 were observed only in cheeses containing the probiotic strains $(4.97 \pm 0.03$ and $4.69 \pm 0.06$ in HPH-P and P-P cheeses, respectively). The highest $\mathrm{pH}$ values $(5.13 \pm 0.07)$ were observed in control Crescenza cheeses obtained from high-pressure homogenized milk, whereas a $\mathrm{pH}$ value of $5.08 \pm 0.05$ characterized the traditional one produced with pasteurized milk.

\section{Changes in Crescenza Microbiota During Storage}

Changes in cheese microflora during the storage at $4^{\circ} \mathrm{C}$ for $12 \mathrm{~d}$ are reported in Table 2 . Initial counts of S. thermophilus were approximately $7.5 \mathrm{log}$ orders and reached values from 8.4 to $8.9 \mathrm{log}$ orders at the expiration day (12 d). Probiotic cultures showed good cell viability in Crescenza cheeses. At d 12 of storage, counts of $L$. paracasei A13 were similar to initial counts (8.0 and $7.6 \mathrm{log}$ orders in HPH-P and P-P cheeses, respec- tively). Lactobacillus acidophilus H5 exhibited higher cell viability in HPH-P cheeses than in P-P cheeses. In the former, initial and final counts were similar (ca. 7 log orders), whereas in P-P cheeses, the initial counts (7.2 log orders) fell to 6.0 log orders by $\mathrm{d} 12$. The presence of the 2 probiotic strains after $12 \mathrm{~d}$ of refrigerated storage was further confirmed by the molecular technique applied (Figure 1). At the beginning ( $1 \mathrm{~d})$ of the storage period, cheeses manufactured with pressurized milk showed counts of yeasts, Enterobacteriaceae, microstaphylococci, and enterococci higher (from 0.6 to 3.1 log orders) than $\mathrm{P}$ cheeses, probably due to the higher efficiency of pasteurization than $\mathrm{HPH}$ to inactivate raw milk microflora. Counts of this non-lactic acid microflora increased slightly $(<0.6$ log orders $)$ in cheeses, with the exception of yeasts in $\mathrm{P}$ and P-P cheeses, Enterobacteriaceae (in HPH and HPH-P cheeses), and enterococci (in HPH-P cheeses; from 1.1 to 2.4 log orders).

\section{FFA}

The cheese FFA contents recorded after 1 and 12 $\mathrm{d}$ of storage at $4^{\circ} \mathrm{C}$, are shown in Table 3. In 1-d-old Crescenza cheeses, the products from high-pressure homogenized milk were characterized by the presence of 18 (HPH cheese) and 17 (HPH-P cheese) medium- and long-chain fatty acids. The cheeses made with pasteurized milk showed a simpler FFA profile lacking of C8:0, C9:0, branched iso and anteiso having 15 and 17 carbon atoms, as well as of long-chain fatty acids such as C18:3 and C20:0. The marked effect of the treatment applied 


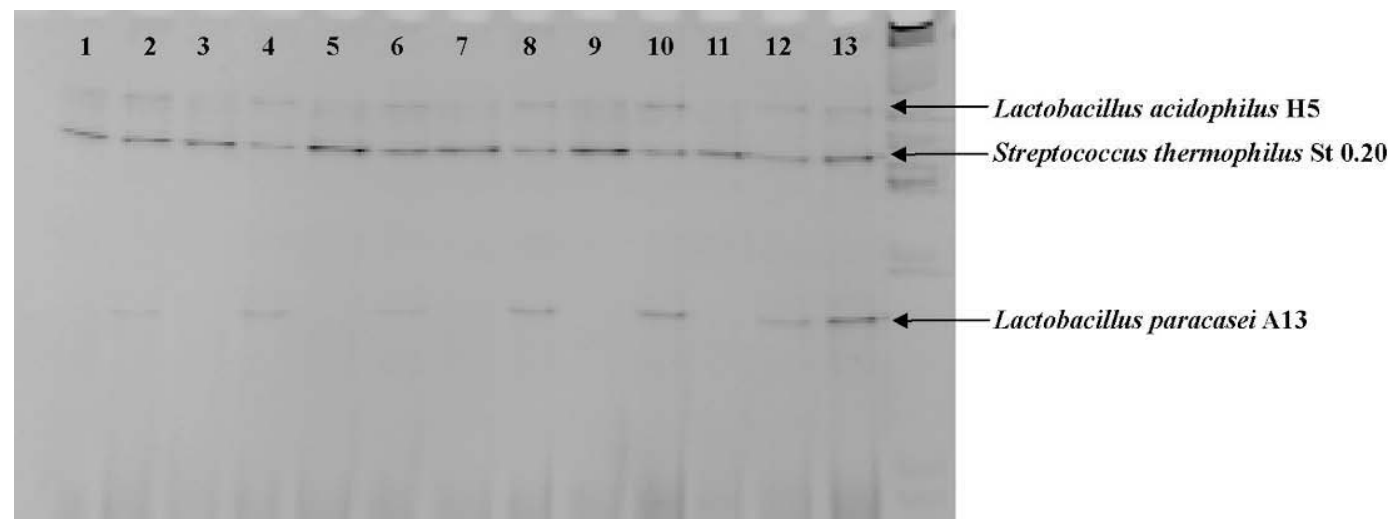

Figure 1. Denaturating gel gradient electrophoresis profiles of amplicons from the different Crescenza cheese types over the refrigerated storage. $1=\mathrm{P}$ cheese $(1 \mathrm{~d}) ; 2=\mathrm{P}-\mathrm{P}$ cheese $(1 \mathrm{~d}) ; 3=\mathrm{HPH}$ cheese $(1 \mathrm{~d}) ; 4=$ HPH-P cheese $(1 \mathrm{~d}) ; 5=\mathrm{P}$ cheese $(5 \mathrm{~d}) ; 6=\mathrm{P}-\mathrm{P}$ cheese $(5 \mathrm{~d}) ;$ $7=\mathrm{HPH}$ cheese $(5 \mathrm{~d}) ; 8=\mathrm{HPH}-\mathrm{P}$ cheese $(5 \mathrm{~d}) ; 9=\mathrm{P}$ cheese $(12 \mathrm{~d}) ; 10=\mathrm{P}-\mathrm{P}$ cheese $(12 \mathrm{~d}) ; 11=\mathrm{HPH}$ cheese $(12 \mathrm{~d}) ; 12=\mathrm{HPH}-\mathrm{P}$ cheese $(12$ d); 13 = DNA mix of the inoculated strains. $\mathrm{HPH}=$ Crescenza cheese from high-pressure homogenized milk; HPH-P = Crescenza cheese from high-pressure homogenized milk with added probiotic bacteria; $\mathrm{P}=$ Crescenza cheese from pasteurized milk; $\mathrm{P}-\mathrm{P}=\mathrm{Crescenza}$ cheese from pasteurized milk with added probiotic bacteria.

to milk was also evident at the date of expiration. In fact, the FFA patterns of cheese from pasteurized milk remained qualitatively unmodified with respect to the beginning of storage and simpler if compared with those of $\mathrm{HPH}$ cheese. However, for all cheeses, the release of almost all the FFA increased during the storage. Particularly, the total FFA mean concentrations after $12 \mathrm{~d}$ of refrigerated storage were 1,462.3, 812.6, 550.1, and $313.3 \mathrm{ppm}$ in HPH, HPH-P, P, and P-P cheeses, respectively. The presence of probiotic cultures caused severe reduction of the total FFA concentration, independently of the milk treatment. However in HPH-P cheese, a marked increase of C18:2 was observed. In all the cheeses analyzed at the end of the storage, the most abundant FFA were C14:0, C16:0, C18:0, and C18:1.

Table 3. Free fatty acids $(\mathrm{ppm}) \pm$ standard deviation in the different types of 1 - and 12-d-old Crescenza cheeses

\begin{tabular}{|c|c|c|c|c|c|c|c|c|}
\hline \multirow[b]{3}{*}{ FFA } & \multicolumn{8}{|c|}{ Cheese type $^{1}$} \\
\hline & \multicolumn{2}{|c|}{$\mathrm{P}$ cheese } & \multicolumn{2}{|c|}{ P-P cheese } & \multicolumn{2}{|c|}{ HPH cheese } & \multicolumn{2}{|c|}{ HPH-P cheese } \\
\hline & $1 \mathrm{~d}$ & $12 \mathrm{~d}$ & $1 \mathrm{~d}$ & $12 \mathrm{~d}$ & $1 \mathrm{~d}$ & $12 \mathrm{~d}$ & $1 \mathrm{~d}$ & $12 \mathrm{~d}$ \\
\hline C8:0 & $-^{2}$ & - & - & - & $4.7 \pm 0.9$ & $6.0 \pm 0.2$ & $2.4 \pm 0.9$ & $2.8 \pm 0.9$ \\
\hline C10:0 & - & $4.5 \pm 0.9$ & - & - & $26.3 \pm 1.0$ & $27.1 \pm 1.7$ & $11.1 \pm 1.2$ & $13.5 \pm 2.0$ \\
\hline C12:0 & - & $18.0 \pm 1.9$ & - & $1.3 \pm 0.3$ & $36.3 \pm 3.1$ & $46.0 \pm 10.0$ & $18.6 \pm 1.7$ & $22.9 \pm 1.9$ \\
\hline C14:0 & $3.4 \pm 0.8$ & $63.9 \pm 2.1$ & $2.4 \pm 0.5$ & $56.7 \pm 2.0$ & $81.0 \pm 2.2$ & $162.2 \pm 22.0$ & $58.5 \pm 9.3$ & $79.6 \pm 11.2$ \\
\hline C15:0 & - & $6.6 \pm 1.4$ & $1.0 \pm 0.1$ & $45.1 \pm 1.9$ & $9.7 \pm 1.0$ & $26.8 \pm 0.7$ & $7.9 \pm 2.4$ & $11.2 \pm 0.9$ \\
\hline C16:0 & $16.4 \pm 1.2$ & $204.8 \pm 10.4$ & $7.0 \pm 0.4$ & $176.8 \pm 11.2$ & $212.0 \pm 14.5$ & $541.6 \pm 33.1$ & $166.0 \pm 30.5$ & $253.3 \pm 30.7$ \\
\hline C16:1 & - & $11.6 \pm 2.0$ & - & - & $8.9 \pm 1.1$ & $30.3 \pm 1.9$ & $7.1 \pm 1.4$ & $13.3 \pm 1.9$ \\
\hline i-C17:0 & - & - & - & - & $3.2 \pm 0.7$ & $9.4 \pm 1.8$ & $2.3 \pm 1.1$ & - \\
\hline $\mathrm{a}-\mathrm{C} 17: 0$ & - & $1.8 \pm 0.9$ & - & - & $2.7 \pm 0.4$ & $8.1 \pm 0.9$ & $1.8 \pm 0.2$ & $2.9 \pm 0.5$ \\
\hline C17:0 & - & $3.4 \pm 0.8$ & - & $2.3 \pm 0.9$ & $4.8 \pm 1.0$ & $12.9 \pm 0.9$ & $2.8 \pm 0.7$ & $5.0 \pm 1.1$ \\
\hline C18:0 & $13.0 \pm 1.4$ & $143.0 \pm 2.5$ & $5.0 \pm 0.7$ & $25.8 \pm 2.5$ & $118.0 \pm 15.0$ & $213.8 \pm 11.5$ & $65.2 \pm 2.3$ & $108.0 \pm 20.9$ \\
\hline
\end{tabular}

${ }^{1} \mathrm{HPH}=$ Crescenza cheese from high-pressure homogenized milk; HPH-P = Crescenza cheese from high-pressure homogenized milk with added probiotic bacteria; $\mathrm{P}=$ Crescenza cheese from pasteurized milk; P-P = Crescenza cheese from pasteurized milk with added probiotic bacteria.

${ }^{2}$ Not detected. 


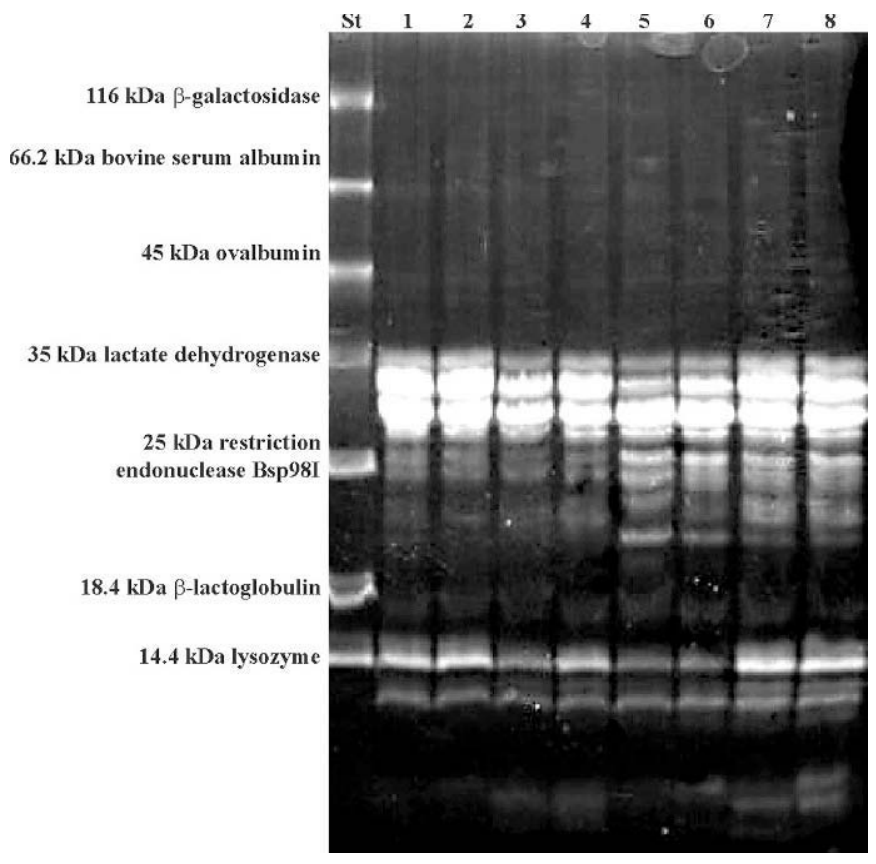

Figure 2. The SDS-PAGE profiles of the different Crescenza cheese types after 1 and $12 \mathrm{~d}$ of refrigerated storage. $\mathrm{St}=\mathrm{SDS}-\mathrm{PAGE}$ molecular weight standard broad range; $1=\mathrm{P}-\mathrm{P}$ cheese $(1 \mathrm{~d}) ; 2=\mathrm{P}$ cheese ( $1 \mathrm{~d}) ; 3=\mathrm{HPH}-\mathrm{P}$ cheese $(1 \mathrm{~d}) ; 4=\mathrm{HPH}$ cheese $(1 \mathrm{~d}) ; 5=\mathrm{P}$ $\mathrm{P}$ cheese $(12 \mathrm{~d}) ; 6=\mathrm{P}$ cheese $(12 \mathrm{~d}) ; 7=$ HPH-P cheese $(12 \mathrm{~d}) ; 8=$ $\mathrm{HPH}$-cheese $(12 \mathrm{~d}) . \mathrm{HPH}=$ Crescenza cheese from high-pressure homogenized milk; HPH-P = Crescenza cheese from high-pressure homogenized milk with added probiotic bacteria; $\mathrm{P}=$ Crescenza cheese from pasteurized milk; $\mathrm{P}-\mathrm{P}=$ Crescenza cheese from pasteurized milk with added probiotic bacteria.

\section{Proteolytic Patterns and AA Profile}

In Figure 2, the SDS-PAGE profiles of the different Crescenza cheeses after 1 and $12 \mathrm{~d}$ of refrigerated storage are shown. Both the initial milk treatment and the probiotic cultures affected the proteolytic patterns, independently from the storage time. In fact, 2 bands having molecular weight $<14.4 \mathrm{kDa}$ were present only in the profiles of cheeses from pressurized milk (HPH and HPH-P cheeses). The addition of probiotic cultures increased the product proteolysis. In fact, after $12 \mathrm{~d}$ of refrigerated storage, the disappearance of the 2 bands having molecular weight $<14.4 \mathrm{kDa}$ was observed in HPH-P cheeses.

Otherwise, the presence of the probiotic strains remarkably increased the cheese FAA concentrations, independently of the milk treatment (Table 4). In fact, the addition of probiotic cultures remarkably increased the concentration of all AA except Ala, Gln, and Ser. The most complex FAA profiles were detected in probiotic cheeses from high-pressure-treated milk, whereas Crescenza from pasteurized milk showed few FAA at lower concentrations. Comparing the AA data obtained from $\mathrm{P}$ and $\mathrm{HPH}$ cheese, the hyperbaric treatment significantly $(P<0.05)$ increased the release of Ala, Asp, Phe, Gly, Gln, Lys, Ser, Tyr, Thr, and Val while decreasing the accumulation of Met. In HPH-P cheeses, there was the accumulation of Asp, Gln, His, Lys, Pro, Ser, and Tyr and the decrease of Asp, Ala, Arg, Phe, Gly, and Thr.

\section{GC-MS-SPME Profiles}

The GC-MS-SPME analysis was performed on the different cheese types after 1 and $12 \mathrm{~d}$ of storage. Initially, the volatile profiles of cheeses from pasteurized milk consisted mainly of molecules such as 2-propanone, acetaldehyde, acetoin, acetic acid, hexanol, and hexanal, whereas butanoic, hexanoic, and octanoic acids were slightly present. In contrast, these last compounds largely characterized the GC-MS-SPME profiles of cheeses from HPH-treated milk. At d 12, acetoin areas decreased in all samples; the same behavior, with the exception of P-P cheese, was observed for acetic acid. Butanoic, hexanoic, octanoic, and decanoic acid areas increased in all cheeses, although the P-P cheese showed the smallest amounts. Acetaldehyde fairly decreased in cheeses made from pasteurized milk (data not shown).

\section{Organoleptic Features}

The results of the evaluation of sensory attributes are shown in Table 5. No significant differences were found for the descriptors salty and creamy. The remaining attributes showed significant $(P<0.05)$ differences for P Crescenza cheese and HPH-P cheese. The $\mathrm{P}$ cheeses were more appreciated than HPH, HPH-P, and P-P cheeses for acid, piquant, bitter, sweet, milky, and overall impression. However, no significant differences, for attributes such as acid, piquant, sweet, milky, salty, creamy, and overall acceptance, were found among HPH, HPH-P, and P-P Crescenza.

\section{DISCUSSION}

In this study, the HPH treatment resulted in inactivation of yeasts, Enterobacteriaceae, and enterococci comparable to pasteurization. However, it was less effective in the reduction of lactobacilli and microstaphylococci. The data obtained were in accordance with previous literature reports (Lanciotti et al., 2006, 2007a,b). The HPH of milk induced significant and selective changes also in cheese microbiota. In fact, at the end of the storage period, Enterobacteriaceae, mesophilic bacteria, enterococci, and microstaphylococci showed higher levels in HPH cheeses (from high-pressure ho- 
Table 4. Free $\mathrm{AA}^{1}(\mathrm{mg} / 100 \mathrm{~g}) \pm \mathrm{SD}$ in the different types of Crescenza cheeses after $12 \mathrm{~d}$ of refrigerated storage

\begin{tabular}{|c|c|c|c|c|}
\hline \multirow[b]{2}{*}{ Free AA } & \multicolumn{4}{|c|}{ Cheese type $^{2}$} \\
\hline & $\mathrm{HPH}$ & HPH-P & $\mathrm{P}$ & P-P \\
\hline Asp & $-^{3}$ & $3.00 \pm 0.40^{\mathrm{a}}$ & - & $4.89 \pm 0.73^{\mathrm{b}}$ \\
\hline$\gamma$-Aminobutyric acid & - & - & - & - \\
\hline Ala & $23.90 \pm 1.22^{\mathrm{a}}$ & $7.67 \pm 0.76^{\mathrm{b}}$ & $14.1 \pm 1.07^{\mathrm{c}}$ & $10.5 \pm 1.70^{\mathrm{b}}$ \\
\hline Arg & $1.50 \pm 0.40^{\mathrm{a}}$ & $6.05 \pm 0.95^{\mathrm{b}}$ & $0.81 \pm 0.21^{\mathrm{a}}$ & $8.22 \pm 0.79^{c}$ \\
\hline Asn & $0.58 \pm 0.08^{\mathrm{ab}}$ & $0.80 \pm 0.20^{\mathrm{a}}$ & - & $0.56 \pm 0.13^{\mathrm{b}}$ \\
\hline Phe & $3.52 \pm 0.76^{\mathrm{a}}$ & $5.68 \pm 1.10^{\mathrm{b}}$ & $1.31 \pm 0.37^{\mathrm{c}}$ & $7.21 \pm 0.83^{\mathrm{b}}$ \\
\hline Gly & $0.52 \pm 0.22^{\mathrm{a}}$ & $0.85 \pm 0.22^{\mathrm{a}}$ & - & $1.29 \pm 0.28^{\mathrm{b}}$ \\
\hline Gln & $1.50 \pm 0.04^{\mathrm{a}}$ & $1.52 \pm 0.02^{\mathrm{a}}$ & $1.18 \pm 0.06^{\mathrm{b}}$ & $1.34 \pm 0.19^{\mathrm{ab}}$ \\
\hline Ile & $1.44 \pm 0.35^{\mathrm{a}}$ & $3.65 \pm 0.31^{\mathrm{b}}$ & $0.65 \pm 0.30^{\mathrm{a}}$ & $3.79 \pm 0.60^{\mathrm{b}}$ \\
\hline His & $1.51 \pm 0.43^{\mathrm{a}}$ & $3.02 \pm 0.90^{\mathrm{b}}$ & $0.68 \pm 0.36^{\mathrm{a}}$ & $1.6 \pm 0.20^{\mathrm{a}}$ \\
\hline Lys & $0.53 \pm 0.23^{\mathrm{a}}$ & $3.24 \pm 0.50^{\mathrm{b}}$ & - & $1.97 \pm 0.55^{\mathrm{c}}$ \\
\hline Met & - & $0.76 \pm 0.35^{\mathrm{a}}$ & $0.55 \pm 0.30^{\mathrm{a}}$ & $0.78 \pm 0.32^{\mathrm{a}}$ \\
\hline Orn & - & - & - & - \\
\hline Pro & $2.29 \pm 0.70^{\mathrm{ac}}$ & $4.55 \pm 0.50^{b}$ & $1.34 \pm 0.56^{\mathrm{a}}$ & $4.1 \pm 0.70^{\mathrm{bc}}$ \\
\hline Ser & $0.79 \pm 0.20^{\mathrm{a}}$ & $0.53 \pm 0.25^{\mathrm{a}}$ & - & - \\
\hline Tyr & $5.71 \pm 0.61^{\mathrm{a}}$ & $5.92 \pm 1.47^{\mathrm{a}}$ & $2.46 \pm 0.76^{\mathrm{b}}$ & $3.74 \pm 0.75^{\mathrm{ab}}$ \\
\hline Thr & $0.87 \pm 0.15^{\mathrm{a}}$ & $1.82 \pm 1.18^{\mathrm{a}}$ & - & $2.20 \pm 0.41^{\mathrm{a}}$ \\
\hline Val & $2.12 \pm 0.46^{\mathrm{a}}$ & $3.74 \pm 0.95^{\mathrm{a}}$ & - & $3.72 \pm 0.57^{\mathrm{a}}$ \\
\hline Cys and cystine & - & - & - & - \\
\hline Trp & - & - & - & - \\
\hline
\end{tabular}

${ }^{\mathrm{a}-\mathrm{C}}$ For each line considered, values with the same superscript are not statistically different $(P>0.05)$.

${ }^{1}$ Amino acid values are the mean of 3 replicate samples from cheese of the same day of production.

${ }^{2} \mathrm{HPH}=$ Crescenza cheese from high-pressure homogenized milk; HPH-P = Crescenza cheese from highpressure homogenized milk with added probiotic bacteria; $\mathrm{P}=$ Crescenza cheese from pasteurized milk; $\mathrm{P}$ $\mathrm{P}=$ Crescenza cheese from pasteurized milk with added probiotic bacteria.

${ }^{3}$ Not detected.

mogenized milk) compared with $\mathrm{P}$ cheeses (from pasteurized milk), which had the highest yeast counts. A shift in microbial population in cheeses obtained from HPH goat and cow milks has already been observed by Guerzoni et al. (1999) and Lanciotti et al. (2004a), respectively.
Our data suggested that the HPH treatment of milk significantly incresed the viability during the storage of $L$. acidophilus H5. In fact, for this probiotic strain, Crescenza obtained from HPH cheese was a better carrier than that from pasteurized milk, allowing the maintenance of cell loads of about $7 \mathrm{log} \mathrm{cfu} / \mathrm{g}$ over the

Table 5. Main scores \pm SD obtained for each attribute in the different types of Crescenza cheese after $8 \mathrm{~d}$ of refrigerated storage ${ }^{1}$

\begin{tabular}{lcccc}
\hline & \multicolumn{4}{c}{ Cheese type $^{2}$} \\
\cline { 2 - 5 } Sensory attribute & HPH-P & HPH & P-P & P \\
\hline Acid & $6.3 \pm 2.4^{\mathrm{a}}$ & $5.7 \pm 2.6^{\mathrm{ab}}$ & $5.7 \pm 2.8^{\mathrm{ab}}$ & $2.9 \pm 2.3^{\mathrm{b}}$ \\
Piquant & $5.0 \pm 3.2^{\mathrm{a}}$ & $4.4 \pm 3.1^{\mathrm{a}}$ & $3.0 \pm 2.6^{\mathrm{ab}}$ & $1.0 \pm 0.9^{\mathrm{b}}$ \\
Bitter & $5.4 \pm 2.9^{\mathrm{ac}}$ & $5.8 \pm 2.8^{\mathrm{c}}$ & $2.6 \pm 2.5^{\mathrm{ab}}$ & $1.2 \pm 0.9^{\mathrm{b}}$ \\
Sweet & $1.9 \pm 1.1^{\mathrm{a}}$ & $2.3 \pm 1.45^{\mathrm{ab}}$ & $3.8 \pm 2.7^{\mathrm{ab}}$ & $4.9 \pm 2.8^{\mathrm{b}}$ \\
Milky & $3.0 \pm 2.2^{\mathrm{a}}$ & $3.3 \pm 2.7^{\mathrm{a}}$ & $3.7 \pm 2.0^{\mathrm{ab}}$ & $6.1 \pm 1.1^{\mathrm{b}}$ \\
Salty & $4.9 \pm 2.0^{\mathrm{a}}$ & $4.4 \pm 2.0^{\mathrm{a}}$ & $4.4 \pm 2.3^{\mathrm{a}}$ & $4.3 \pm 2.1^{\mathrm{a}}$ \\
Creamy & $5.2 \pm 2.7^{\mathrm{a}}$ & $5.4 \pm 2.8^{\mathrm{a}}$ & $6.8 \pm 2.8^{\mathrm{a}}$ & $5.8 \pm 1.4^{\mathrm{a}}$ \\
Overall acceptance & $3.9 \pm 1.9^{\mathrm{a}}$ & $5.0 \pm 1.8^{\mathrm{a}}$ & $5.0 \pm 1.4^{\mathrm{a}}$ & $7.1 \pm 0.9^{\mathrm{b}}$ \\
\hline
\end{tabular}

\footnotetext{
${ }^{a-c}$ For each line considered, values with the same superscript are not statistically different $(P>0.05)$.

${ }^{1}$ For each attribute, the results of the 1-way ANOVA are reported. The results are the mean of the panelist evaluations based on the scale of 1 (low or poor) to 10 (high or very excellent).

${ }^{2} \mathrm{HPH}=$ Crescenza cheese from high-pressure homogenized milk; HPH-P = Crescenza cheese from highpressure homogenized milk with added probiotic bacteria; $\mathrm{P}=$ Crescenza cheese from pasteurized milk; P$\mathrm{P}=$ Crescenza cheese from pasteurized milk with added probiotic bacteria.
} 
refrigerated storage. This positive effect can be attributed to increased precocious availability of low molecular weight peptides and FFA such as C18:1, essential for the growth of many lactic acid bacteria (Guerzoni et al., 2001; Partanen et al., 2001; Endo et al., 2006). On the other hand, the FFA concentrations showed that the HPH treatment markedly increased the lipolysis even after $1 \mathrm{~d}$ of storage at $4^{\circ} \mathrm{C}$. The early release of FFA in milk and cheeses has been mainly attributed to the reduction of fat globule associated to the barotolerance of endogenous lipoprotein lipase (Hayes and Kelly, 2003) as well as to the activation of the endogenous lipoprotein lipase by HPH treatment (Lanciotti et al., 2006). In the present, the precocious release of FFA was favored also by the delay between the HPH and the cheesemaking $(12 \mathrm{~h})$.

The electrophoretic patterns obtained for the different cheeses and the precocious early release of branched-chain fatty acids (BCFA) showed that Crescenza made from $\mathrm{HPH}$-treated milk was characterized by a more precocious proteolysis, suggesting that also the activity of native protease was enhanced in $\mathrm{HPH}$ chesses. In fact, AA catabolism is 1 plausible explanation for the occurrence of BCFA in cheeses, because milk fat lacks BCFA (Ganesan and Weimer, 2004). Free fatty acids can originate from lipolysis, proteolysis, and lactose fermentation. Endogenous or microbial esterases and lipases may cause the release of linear-chain FA, whereas proteolytic enzymes are responsible for the formation of C15:0 iso, C15:0 anteiso, and C17:0 anteiso originating from the breakdown of Ile and Leu (Berdague et al., 1987). The Lactobacillus casei viability during the storage was less affected by the initial milk treatment. The L. casei strain used maintained, in both types of cheeses, viable cell numbers higher than $7.0 \mathrm{log}$ $\mathrm{cfu} / \mathrm{g}$. On the other hand, the high peptidase activities of this species are well documented (Fox et al., 1998). In fact, among the mesophilic nonstarter lactic acid bacteria, although with strain-dependent variations, Lactobacillus plantarum and $L$. casei are reported to contribute to the secondary proteolysis through various peptidase activities (Fox et al., 1998), also under the hostile cheese-like conditions (Laan et al., 1998; Gobbetti et al., 1999a,b).

The HPH treatment also induced a more extensive proteolysis and lipolysis over the storage period. These data are in agreement with previous literature reports (Guerzoni et al., 1999; Kheadr et al., 2002; Lanciotti et al., 2004a, 2006). High-pressure homogenization is reported to affect size of fat globules, protein or polysaccharide denaturation, aggregation, and microparticle formation (Sandra and Dalgleish, 2005). Moreover, this technology can induce the formation of complexes among proteins, fat globules, and polysaccharides. The effects on these constituents, in addition to a modification of their functional properties and changes in food microstructure, can also affect the activity and specificity of the enzymes as well as the susceptibility of the macromolecules present in the system to the enzymatic attack, modifying the proteolytic and lipolytic patterns of products (Guerzoni et al., 1999; Wuytack et al., 2002). However, also, the different composition of microbial population and the higher levels of enterococci and microstaphylococci could have favored the accumulation of FFA and the release of AA.

The addition of probiotic cultures significantly modified the cheese proteolytic and lipolytic patterns. In agreement with our findings, Ong et al. (2007) showed an increased proteolysis in probiotic Cheddar cheeses and particularly in those with the addition of $L$. casei 279 and L. paracasei LAFTIs L26. By contrast, although some literature reports showed that probiotic lactobacilli can contribute to milk fat lipolysis (Alonso et al., 2003; Yadav et al., 2007), a reduction of almost all the FFA detected was observed in the presence of the probiotic cultures independently on the initial milk treatment. This reduction can be attributed to the decrease of the lipase and esterase activities determined to high initial inoculum level of probiotic strains and to the consumption by lactic acid bacteria of some FFA. In fact, Fox et al. (1998) reported the negative effects of nonstarter lactic acid bacteria elevated counts on their lipase and esterase activity in cheeses. Moreover, Endo et al. (2006) showed the strong promotion activities for Lactobacillus spp. growth of specific FFA, mainly octadecenoic and trans fatty acids, due to their incorporation into membrane lipids. In addition to the diminution of almost all FFA, the inclusion of probiotic cultures provoked the marked increase in Crescenza obtained from HPH milk of C18:2. The release of C18:2 by L. acidophilus and $L$. casei has already been observed by Yadav et al. (2007). Although these authors also demonstrated the ability of the probiotic strains considered to produce conjugated linoleic acid using the linoleic acid released, the ability of lactic acid bacteria to produce conjugated linoleic acids in media supplemented with exogenous linoleic acid is well documented (Alonso et al., 2003; Ogawa et al., 2005). Conjugated linoleic acids, a novel type of beneficial functional lipids, have several beneficial properties (Ogawa et al., 2005).

The different aminoacidic content and FFA profiles of HPH-P and P-P cheeses (from pasteurized milk plus probiotics) can be attributed to protein conformational and fat globule changes induced by $\mathrm{HPH}$ treatment 
and consequently to their different exposure of protein molecules to enzymatic attack (Guerzoni et al., 1999).

Although differences in proteolytic, lipolytic, and volatile molecule profiles in relation to HPH treatment were recorded, the sensory analysis, performed after 8 $\mathrm{d}$ of refrigerated storage, pointed out significant differences only between $\mathrm{P}$ cheeses and the other type of cheeses. On the contrary, P-P, HPH, and HPH-P cheeses were perceived as similar by the panelists for attributes such as acid, piquant, sweet, milky, salty, creamy, and overall acceptance. The traditional product (P cheese) received the highest scores with respect to the other ones. It must be admitted that the sensorial analysis was performed by Italian panelists, who are accustomed to the consumption of the traditional product that is creamy, smooth, yeasty, and slightly tart. The optimal characteristics for the consumption are generally achieved after $7 \mathrm{~d}$ of storage at $4^{\circ} \mathrm{C}$ without temperature abuse. A prolonged or improper storage can make the paste of the Crescenza cheese yellow and develop a sour taste due to the growth of spoilage microorganisms. Moreover, Crescenza freshness is generally associated with low acidity, limited proteolysis, and no bitter or sour taste (Benedetti et al., 2005). Thus, the initial P-P, HPH, and HPH-P cheeses' high proteolysis, mainly due to the initial milk treatment and to the presence of probiotic cultures, accelerated the product maturation and make these products similar to traditional Crescenza closed to the expiration date.

\section{CONCLUSIONS}

The use of milk treated by HPH, instead of pasteurized milk, increased the maintenance of the cell viability during the storage of $L$. acidophilus. In addition, this technology contributes, together with the adjunct probiotic cultures, to the modification of the sensorial features of the products. In fact, in recent years, there has been an increasing demand for new varieties of dairy products similar to traditional ones for safety but differentiated for sensory, rheological, and nutritional characteristics (Duncan, 1998). For instance, the increase of the release of $\mathrm{C} 18: 2$ in homogenized products could further improve the functional properties of $\mathrm{HPH}$ P-cheese. However, additional studies will be required to evaluate if $\mathrm{HPH}$ can completely replace the thermal treatment of the cheese milk sanification.

\section{ACKNOWLEDGMENTS}

This research was partially supported by the Project of Scientific and Technological Cooperation SECYTMAE (Argentina-Italy) IT/PA05-A/IX/010 "Potenzialità dell'applicazione delle alte pressioni di omogeneizzazione per la produzione di prodotti fermentati probiotici." We are grateful to Federica Mambelli (Bertinoro, Italy) and her productive staff for the technical support during cheesemaking. Jorge Reinheimer and Gabriel Vinderola are main researcher and research assistant, respectively, from Consejo Nacional de Investigaciones Científicas y Técnicas. Patricia Burns is a doctoral fellow from Consejo Nacional de Investigaciones Científicas y Técnicas.

\section{REFERENCES}

Alonso, L., E. P. Cuesta, and S. E. Gilliland. 2003. Production of free conjugated linoleic acid by Lactobacillus acidophilus and Lactobacillus casei of human origin. J. Dairy Sci. 86:1941-1946.

Andrews, W. H., and T. S. Hammack. 1998. Salmonella. Chapter 5 in Bacteriological Analytical Manual Online. http://www.cfsan. fda.gov/

Benedetti, S., N. Sinelli, S. Buratti, and M. Riva. 2005. Shelf life of Crescenza cheese as measured by electronic nose. J. Dairy Sci. 88:3044-3051.

Berdagué, J. L., R. Jeunet, and R. Grappin. 1987. Ripening and quality of Gruyére de Comté cheese. III. Lactic acid fermentation and levels of volatile fatty acids in Comté cheese. Lait 67:249-263.

Bergamini, C. V., E. R. Hynes, and C. A. Zalazar. 2006. Influence of probiotic bacteria on the proteolysis profile of a semi-hard cheese. Int. Dairy J. 16:856-866.

Blanchette, L., D. Roy, G. Belanger, and S. F. Gauthier. 1996. Production of cottage cheese using dressing fermented by bifidobacteria. J. Dairy Sci. 79:8-15.

Bottazzi, V. 1993. Formaggio Crescenza. Pages 236-239 in Microbiologia Lattiero-Casearia. Edagricole-Edizioni Agricole della Calderini S.R.L., Bologna, Italy.

Boylston, T. D., C. G. Vinderola, H. B. Ghoddusi, and J. A. Reinheimer. 2004. Incorporation of Bifidobacterium into cheeses: Challenges and rewards. Int. Dairy J. 14:375-387.

Brinpez, W. J., A. X. Roig-Sagueìs, M. M. Hernaìndez Herrero, and B. G. Loìpez. 2006. Inactivation of Listeria innocua in milk and orange juice by ultrahigh-pressure homogenization. J. Food Prot. 69:86-92.

Buriti, F. C. A., J. S. da Rocha, and S. M. I. Saad. 2005. Incorporation of Lactobacillus acidophilus in Minas fresh cheese and its implications for textural and sensorial properties during storage. Int. Dairy J. 15:1279-1288.

Corbo, M. R., M. Albenzio, M. De Angelis, A. Sevi, and M. Gobbetti. 2001. Microbiological and biochemical properties of canestrato pugliese hard cheese supplemented with bifidobacteria. J. Dairy Sci. 84:551-561.

de Jong, C., and H. T. Badings. 1990. Determination of free fatty acids in milk and cheese. Procedures for extraction, clean up, and capillary gas chromatographic analysis. J. High Resolut. Chromatogr. 13:94-98.

Diels, A. M. J., and C. W. Michiels. 2006. High-pressure homogenization as non thermal technique for the inactivation of microorganisms. Crit. Rev. Microbiol. 32:201-216.

Duncan, S. E. 1998. Dairy products: The next generation. Altering the image of dairy products through technology. J. Dairy Sci. 81:877-883.

Endo, Y., S. Kamisada, K. Fujimoto, and T. Saito. 2006. Trans fatty acids promote the growth of some Lactobacillus strains. J. Gen. Appl. Microbiol. 52:29-35.

Fasoli, S., M. Marzotto, L. Rizzotti, F. Rossi, F. Dellaglio, and S. Torriani. 2003. Bacterial composition of commercial probiotic products as evaluated by PCR-DGGE analysis. Int. J. Food Microbiol. 82:59-70. 
Fox, P. F., P. L. H. McSweeney, and C. M. Lynch. 1998. Significance of non-starter lactic acid bacteria in Cheddar cheese. Aust. J. Dairy Technol. 53:83-89.

Gallardo-Escamilla, F. J., A. L. Kelly, and C. M. Delahunty. 2007. Mouthfeel and flavour of fermented whey with added hydrocolloids. Int. Dairy J. 17:308-315.

Ganesan, B., and B. C. Weimer. 2004. Role of aminotransferase IlvE in production of branched-chain fatty acids by Lactococcus lactis subsp. lactis. Appl. Environ. Microbiol. 70:638-664.

Gobbetti, M., A. Corsetti, E. Smacchi, A. Zocchetti, and M. De Angelis. 1998. Production of Crescenza cheese by incorporation of bifidobacteria. J. Dairy Sci. 81:37-47.

Gobbetti, M., R. Lanciotti, M. De Angelis, M. R. Corbo, R. Massini, and P. F. Fox. 1999a. Study of the effects of temperature, $\mathrm{pH}$ and $\mathrm{NaCl}$ on the peptidase activities of non-starter lactic acid bacteria (NSLAB) by quadratic response surface methodology. Int. Dairy J. 9:865-875.

Gobbetti, M., R. Lanciotti, M. De Angelis, M. R. Corbo, R. Massini, and P. F. Fox. 1999b. Mathematical modelling of the effects of temperature, $\mathrm{pH}, \mathrm{NaCl}$ and $a w$ on the proteolytic and lipolytic activities of cheese-related lactic acid bacteria. Enzyme Microb.Technol. 25:795-809.

Gomes, A. M. P., F. X. Malcata, F. A. M. Klaver, and H. J. Grande. 1995. Incorporation and survival of Bifidobacterium sp. strain Bo and Lactobacillus acidophilus strain Ki in a cheese product. Neth. Milk Dairy J. 49:71-95.

Guerzoni, M. E., R. Lanciotti, and P. S. Cocconcelli. 2001. Alteration in cellular fatty acid composition as a response to salt, acid, oxidative and thermal stresses in Lactobacillus helveticus. Microbiology $147: 2255-2264$.

Guerzoni, M. E., L. Vannini, C. Chaves-Lopez, R. Lanciotti, G. Suzzi, and A. Gianotti. 1999. Effect of high pressure homogenization on microbial and chemico-physical characteristics of goat cheeses. J. Dairy Sci. 82:851-862.

Guerzoni, M. E., L. Vannini, R. Lanciotti, and F. Gardini. 2002 Optimisation of the formulation and of the technological process of egg-based products for the prevention of Salmonella enteritidis survival and growth. Int. J. Food Microbiol. 73:367-374.

Hayes, M. G., and A. L. Kelly. 2003. High pressure homogenisation of milk (b) effects on indigenous enzymatic activity. J. Dairy Res. 70:307-313.

Heller, K. J., W. Bockelmann, J. Schrezenmeir, and M. de Vrese. 2003. Cheese and its potential as a probiotic food. Pages 203-225 in Handbook of Fermented Functional Foods. E. R. Farnworth, ed. CRC Press, Boca Raton, FL.

IDF. 1964. Determination of the protein content of processed cheese products. IDF Standard 25. Int. Dairy Fed., Brussels, Belgium.

IDF. 1970. Determination of dry matter content in whey cheese. IDF Standard 58. Int. Dairy Fed., Brussels, Belgium.

IDF. 1986. Cheese and processed cheese products. Determination of fat content. IDF Standard 5B. Int. Dairy Fed., Brussels, Belgium.

IDF. 1993. Milk - Determination of nitrogen content. IDF Standard 20B. Int. Dairy Fed., Brussels, Belgium.

IDF. 1995. Detection and enumeration of Lactobacillus acidophilus. Bull. No. 306/1995. Int. Dairy Fed., Brussels, Belgium.

ISO. 1988. Sensory analysis. Standard 8589: General guidance for the design of test rooms. Int. Org. Stand., Paris, France.

Izco, J. M., A. Irigoyen, P. Torre, and Y. Barcina. 2000. Effect of the activity levels of the added proteolytic enzyme mixture on free amino acids in ripening Ossau-Iraty cheese. J. Chromatogr. A. 881:69-79.

Kalavrouzioti, I., M. Hatzikamari, E. Litopoulou-Tzanetaki, and N. Tzanetakis. 2005. Production of hard cheese from caprine milk by the use of two types of probiotic cultures as adjuncts. Int. J. Dairy Technol. 58:30-38.

Kasımoglu, A., M. Göncüoğlu, and S. Akgün. 2004. Probiotic white cheese with Lactobacillus acidophilus. Int. Dairy J. 14:10671073.

Kheadr, E. E., J. F. Vachon, P. Paquin, and I. Fliss. 2002. Effect of dynamic high pressure on microbiological, rheological and microstructural quality of Cheddar cheese. Int. Dairy J. 12:435-446.
Kuchroo, C. N., and P. F. Fox. 1982. Soluble nitrogen in Cheddar cheese: Comparison of extraction procedures. Milchwissenschaft 37:331-335.

Laan, H., S. E. Tan, P. Bruinenberg, G. Limsowtin, and M. Broome. 1998. Aminopeptidase activities of starter and non-starter lactic acid bacteria under simulated Cheddar cheese ripening conditions. Int. Dairy J. 8:267-274.

Laemmli, U. K. 1970. Cleavage of structural proteins during the assembly of the head of bacteriophage T4. Nature 227:680-685.

Lanciotti, R., C. Chaves Lopez, F. Patrignani, A. Paparella, M. E. Guerzoni, A. Serio, and G. Suzzi. 2004a. Effects of milk treatment with HPH on microbial population as well as on the lipolytic and proteolytic profiles of Crescenza cheese. Int. J. Dairy Technol. 57:19-25.

Lanciotti, R., F. Patrignani, L. Iucci, M. E. Guerzoni, G. Suzzi, N. Belletti, and F. Gardini. 2007a. Effects of milk high pressure homogenization on biogenic amine accumulation during ripening of ovine and bovine Italian cheeses. Food Chem. 104:693-701.

Lanciotti, R., F. Patrignani, L. Iucci, P. Saracino, and M. E. Guerzoni. 2007b. Potential of high pressure homogenization in the control and enhancement of proteolytic and fermentative activities of some Lactobacillus species. Food Chem. 102:542-550.

Lanciotti, R., L. Vannini, F. Patrignani, L. Iucci, M. Vallicelli, M. Ndagijimana, and M. E. Guerzoni. 2006. Effect of high pressure homogenization of milk on cheese yield and microbiology, lipolysis and proteolysis during ripening of Caciotta cheese. J. Dairy Res. 73:216-226.

Lanciotti, R., L. Vannini, P. Pittia, and M. E. Guerzoni. 2004b. Suitability of high-dynamic-pressure-treated milk for the production of yogurt. Food Microbiol. 21:753-760.

McClain, D., and W. H. Lee. 1988. Development of USDA-FSIS method for isolation of Listeria monocytogenes from raw meat and poultry. J. Assoc. Off. Anal. Chem. 71:660-664.

Medici, M., C. G. Vinderola, and G. Perdigón. 2004. Gut mucosal immunomodulation by probiotic fresh cheese. Int. Dairy J. 14:611-618.

Menéndez, S., J. A. Centeno, R. Godínez, and J. L. Rodríguez-Otero. 2000. Effect of Lactobacillus strains on the ripening and organoleptic characteristics of Arzuá-Ulloa cheese. Int. J. Food Microbiol. 59:37-46.

Neviani, E., and G. Giraffa. 1993. Formaggi freschi e molli e loro differenziazione: Le microflore lattiche. Il Latte 7:776-780.

Ogawa, J., K. S. Kishino, A. Ando, S. Sugimoto, K. Mihara, and S Shimizu. 2005. Production of conjugated fatty acids by lactic acid bacteria. J. Biosci. Bioeng. 100:355-364.

Ong, L., A. Henriksson, and N. P. Shah. 2007. Chemical analysis and sensory evaluation of Cheddar cheese produced with Lactobacillus acidophilus, Lb. casei, Lb. paracasei or Bifidobacterium sp. Int. Dairy J. 17:937-945.

Partanen, L., N. Marttinen, and T. Alatossava. 2001. Fats and fatty acids as growth factors for Lactobacillus delbrueckii. Syst. Appl. Microbiol. 24:500-506.

Phillips, M., K. Kailasapathy, and L. Tran. 2006. Viability of commercial probiotic cultures (L. acidophilus, Bifidobacterium sp., $L$. casei, L. paracasei and L. rhamnosus) in Cheddar cheese. Int. J. Food Microbiol. 108:276-280.

Ross, R. P., G. Fitzgerald, K. Collins, and C. Stanton. 2002. Cheese delivering biocultures - probiotic cheese. Aust. J. Dairy Technol. 57:71-78.

Sandra, S., and D. G. Dalgleish. 2005. Effects of ultra-high-pressure homogenization and heating on structural properties of casein micelles in reconstituted skim milk powder. Int. Dairy J. 15:1095-1104

Songisepp, E., T. Kullisaar, P. Hütt, P. Elias, T. Brilene, M. Zilmer, and M. Mikelsaar. 2004. A new probiotic cheese with antioxidative and antimicrobial activity. J. Dairy Sci. 87:2017-2023.

Theunissen, J., T. J. Britza, S. Torriani, and R. C. Witthuhn. 2005. Identification of probiotic microorganisms in South African products using PCR-based DGGE analysis. Int. Food Microbiol. 98:11-21.

Vinderola, C. G., W. Prosello, D. Ghiberto, and J. A. Reinheimer. 2000 Viability of probiotic (Bifidobacterium, Lactobacillus acidophilus 
and Lactobacillus casei) and nonprobiotic microflora in Argentinean Fresco cheese. J. Dairy Sci. 83:1905-1911.

Vinderola, C. G., and J. A. Reinheimer. 1999. Culture media for the enumeration of Bifidobacterium bifidum and Lactobacillus acidophilus in the presence of yoghurt bacteria. Int. Dairy J. 9:497-505.

Walter, J., G. W. Tannock, A. Tilsala-Timisjarvi, S. Rodtong, D. M. Loach, K. Munro, and T. Alassatova. 2000. Detection and identification of gastrointestinal Lactobacillus species by using denatur- ing gradient gel electrophoresis and species specific primers. Appl. Environ. Microbiol. 66:297-303.

Wuytack, E. Y., A. M. J. Diels, and C. W. Michiels. 2002. Bacterial inactivation by high-pressure homogenisation and high hydrostatic pressure. Int. J. Food Microbiol. 77:205-212.

Yadav, H., S. Jain, and P. R. Sinha. 2007. Production of free fatty acids and conjugated linoleic acid in probiotic dahi containing Lactobacillus acidophilus and Lactobacillus casei during fermentation and storage. Int. Dairy J. 17:1006-1010. 